This is an electronic reprint of the original article. This reprint may differ from the original in pagination and typographic detail.

\author{
Author(s): Marin, Victoria I.; Jääskelä, Päivikki; Häkkinen, Päivi; Juntunen, Merja; Rasku- \\ Puttonen, Helena; Vesisenaho, Mikko
}

Title: $\quad$ Seamless Learning Environments in Higher Education with Mobile Devices and Examples

Year: $\quad 2016$

Version:

Please cite the original version:

Marin, V. I., Jääskelä, P., Häkkinen, P., Juntunen, M., Rasku-Puttonen, H., \& Vesisenaho, M. (2016). Seamless Learning Environments in Higher Education with Mobile Devices and Examples. International Journal of Mobile and Blended Learning, 8(1), 51-68. https://doi.org/10.4018/IJMBL.2016010104

All material supplied via JYX is protected by copyright and other intellectual property rights, and duplication or sale of all or part of any of the repository collections is not permitted, except that material may be duplicated by you for your research use or educational purposes in electronic or print form. You must obtain permission for any other use. Electronic or print copies may not be offered, whether for sale or otherwise to anyone who is not an authorised user. 


\section{Table of Contents}

\section{International Journal of Mobile and Blended Learning}

Volume 8 • Issue 1 • January-March-2016 • ISSN: 1941-8647 • elSSN: 1941-8655

An official publication of the Information Resources Management Association

\section{Guest Editorial Preface}

v

David Parsons, Massey University, Auckland, New Zealand

\section{Research Articles}

1 Teaching Math to Deaf/Hard-of-Hearing (DHH) Children Using Mobile Games: Outcomes with Student and Teacher Perspectives

Brett E. Shelton, Boise State University, Boise, ID, USA

Mary Ann Parlin, Boise State University, Boise, ID, USA

18 What are Tutors' Experiences with Online Teaching? A Phenomenographic Study

Cvetanka Walter, University of Lancaster, Lancaster, UK

34 Fostering Collaborative Learning with Mobile Web 2.0 in Semi-Formal Settings

Daisy Mwanza-Simwami, The Open University, Milton Keynes, UK

51 Seamless Learning Environments in Higher Education with Mobile Devices and Examples

Victoria I. Marín, University of the Balearic Islands, Palma de Mallorca, Spain

Päivikki Jääskelä, Department of Teacher Education, University of Jyvaskyla, Jyvaskyla, Finland

Päivi Häkkinen, Finnish Institute for Educational Research, University of Jyvaskyla, Jyvaskyla, Finland

Merja Juntunen, Department of Teacher Education, University of Jyvaskyla, Jyvaskyla, Finland

Helena Rasku-Puttonen, Department of Teacher Education, University of Jyvaskyla, Jyvaskyla, Finland

Mikko Vesisenaho, Agora Center, University of Jyvaskyla, Jyvaskyla, Finland

\section{COPYRIGHT}

The International Journal of Mobile and Blended Learning (IJMBL) (ISSN 1941-8647; eISSN 1941-8655), Copyright (C) 2016 IGI Global. All rights, including translation into other languages reserved by the publisher. No part of this journal may be reproduced or used in any form or by any means without written permission from the publisher, except for noncommercial, educational use including classroom teaching purposes. Product or company names used in this journal are for identification purposes only. Inclusion of the names of the products or companies does not indicate a claim of ownership by IGI Global of the trademark or registered trademark. The views expressed in this journal are those of the authors but not necessarily of IGI Global.

The International Journal of Mobile and Blended Learning is indexed or listed in the following: ACM Digital Library; Applied Social Sciences Index \& Abstracts (ASSIA); Bacon's Media Directory; Cabell's Directories; Compendex (Elsevier Engineering Index); DBLP; GetCited; Google Scholar; INSPEC; JournalTOCs; Library \& Information Science Abstracts (LISA); MediaFinder; Norwegian Social Science Data Services (NSD); PsycINFO®; SCOPUS; The Index of Information Systems Journals; The Standard Periodical Directory; Ulrich's Periodicals Directory 


\title{
Seamless Learning Environments in Higher Education with Mobile Devices and Examples
}

\author{
Victoria I. Marín, University of the Balearic Islands, Palma de Mallorca, Spain \\ Päivikki Jääskelä, Department of Teacher Education, University of Jyvaskyla, Jyvaskyla, Finland \\ Päivi Häkkinen, Finnish Institute for Educational Research, University of Jyvaskyla, Jyvaskyla, Finland \\ Merja Juntunen, Department of Teacher Education, University of Jyvaskyla, Jyvaskyla, Finland \\ Helena Rasku-Puttonen, Department of Teacher Education, University of Jyvaskyla, Jyvaskyla, Finland \\ Mikko Vesisenaho, Agora Center, University of Jyvaskyla, Jyvaskyla, Finland
}

\begin{abstract}
The use of seamless learning environments that have the potential to support lifelong learning anytime and anywhere has become a reality. In this sense, many educational institutions have started to consider introducing seamless learning environments into their programs. The aim of this study is to analyze how various educational university programs implement the design elements for seamless learning environments with mobile devices. For that purpose, three cases involved in a Finnish teaching development project are explored by conducting semi-structured interviews with key participants. The themes of the interviews were related to the theoretical background for (mobile) seamless learning environments from previous literature. This paper describes the findings of the three cases as common aspects for designing mobile, seamless learning environments; and it proposes a research agenda on challenges related to designing seamless learning environments with the integrated use of mobile devices in the curricula.
\end{abstract}

\section{KEYWORDS}

Blended Learning, Higher Education, Meaningful Learning, Mobile Devices, Personal Learning Environments, Seamless Learning Environments, Web 2.0 Tools

\section{INTRODUCTION}

The twenty-first century has raised educational demands that require new ways of thinking and learning (Kereluik, Mishra, Fahnoe, \& Terry, 2013). These demands include the diffusion of technology into all aspects of personal and professional life (Butson, 2005), the exponential growth of the amount of information available, the growing importance of a knowledge-based economy, and globalization, which is facilitated by technology. 
One of the fastest growing trends, as reported by Johnson, Adams Becker, Estrada, and Freeman (2014), is the growing ubiquity of social media. The authors state that portable, connected, and personal technology is transforming people's lives wherever they go. Ubiquitous learning environments can thus provide possibilities for accessing information, content creation, and communication and sharing in a personalized way through mobile devices (such as smartphones or tablets) at any time and in any place place (Sharples, 2006). This implies that learning can also occur independently from the physical and temporal context (Evans \& Johri, 2008; Salinas, 2012); hence, because it is seamless, it can broaden learning environments from classrooms and other formal places for learning (Partnership for 21 st Century Skills, 2009). The idea is that students can learn whenever they want to in a variety of scenarios, and that they can switch from one scenario or context to another easily and quickly using a personal device as a mediator (Chan et al., 2006; Looi et al., 2010; Wong, 2013). Therefore, a shift to more dynamic conceptions of space-time and an emphasis on lifelong learning is taking place. Seamless learning environments are rooted in two main characteristics of mobile learning that have previously been expressed: personalization and mobility (Wong, 2013a).

"Personalization" is based on student-centered approaches, which prioritize learning as a whole person, including intellect and feelings as well as personal and group processes (Motschnig-Pitrik \& Holzinger, 2002). Furthermore, student-centered approaches emphasize authentic, complex, and ill-defined tasks in order to enhance meaningful and relevant learning experiences (Elen, Clarebout, Léonard, \& Lowyck, 2007; Lombardi, 2007). Much of the research on the use of mobile devices for learning has been conducted either in formal or informal learning environments, but not much research has been done on bridging these two environments (Looi et al., 2010).

This study will provide insights, examples, and challenges for designing seamless learning environments that utilize mobile devices in the higher education context. We will present and discuss the findings of the interview study through three case examples and a synthesis of each. The three cases are related to educational programs that aim to design seamless learning environments. These programs are implemented in the context of the teaching development project of the University of Jyväskylä, Finland.

\section{THEORETICAL BACKGROUND}

Present seamless learning environments can be characterized as being hybrid entities that integrate formal and informal, individual and collaborative, physical and virtual, and local and global elements of learning environments (Häkkinen \& Hämäläinen, 2012; Sharples, 2006). They imply an embodiment of learning into everyday living, or a seamless flow of learning across contexts (Wong $\&$ Looi, 2011). At their best, these learning environments consist of scenarios in which learners are active, productive, creative, and collaborative across different environments (physical or virtual) and settings (formal or informal). Learners use multiple technological devices in diverse ways for information search; knowledge creation; and communication and collaboration with peers, friends, and family, without restrictions of time or location (Chan et al., 2006; Looi et al., 2010). Kuh (1996, p. 136) states that "in seamless learning environments, students are encouraged to take advantage of learning resources that exist both inside and outside of the classroom ... students are asked to use their life experiences to make meaning of material introduced in classes." Moreover, Chan et al. write that seamless learning environments:

“... include learning individually, with another student, a small group, or a large online community, with possible involvement of teachers, mentors, parents, librarians, workplace professionals, and members of other supportive communities, face-to-face or at a distance in places such as classroom, campus, home, workplace, zoo, park, and outdoors." (Chan et al. 2006, p. 10) 
Seow et al. (2008) base their conception of seamless learning environments on the theory of distributed cognition (Hutchins, 1995), which emphasizes interactions of students, artifacts (i.e. items made by people, such as a written essay or a piece of art), and the environment, mediated by technology over space and time in learning. The authors suggest the following components as elements of seamless learning environments: the flexible use of different spaces in learning; time being an essential element in evolving knowledge; authentic contexts of designed activities; a supportive community of learners, teachers, and domain experts; the use of mobile devices and online portals as cognitive tools for learning; and the use of artifacts as products generated by the learners. These elements are helpful in framing our study, and are also related to two other relevant educational ideas posed in this study: "Web 2.0" tools (i.e. those that take advantage of interactive web pages and social media) in generating artifacts and connections with the community, and the concept of the personal learning environment (PLE) as a personal, seamless learning environment, which includes activities, communities, tools, and artifacts viewed from the perspective of each individual.

\section{Web 2.0 Tools}

Social media or Web 2.0 tools, as services that empower learners in creating, sharing, and collaborating (McLoughlin \& Lee, 2010), play a key role in the creation of seamless learning spaces. They are cognitive tools that can support the creation of artifacts in a context and through a community at any time and in any place. Bower, Hedberg, and Kuswara (2010) emphasize the importance of analyzing content-specific knowledge and the pedagogical approaches and modalities of representations mediated by technology when designing learning environments that utilize Web 2.0 tools (Seow et al., 2008). Based on their analysis, as well as Conole's (2007) and Laurillard's (2012) views on learning processes, some aspects of learning environments need to be carefully addressed while selecting the technologies to use:

- Learning goals and objectives (intended learning outcomes);

- Type of content in terms of the knowledge that needs to be represented (factual, procedural, conceptual, or metacognitive);

- Cognitive processes that students are expected to engage in (lower level processes, such as remembering, understanding, and applying, and higher-order processes, such as analyzing, evaluating, and creating) and type of pedagogical approaches adopted (transmissive, dialogic, constructive, or co-constructive);

- Intended learning activities (Conole, 2007; Laurillard, 2012): acquisition, related to assimilative tasks of a passive nature such as reading, viewing, or listening; collaboration, where students contribute to the process of creating knowledge; discussion, where students engage in dialogic or debate activities; investigation, related to the performance of inquiries by students; practice, related to the application of experiential skills in a learning context; and production, related to the construction of an artifact by students;

- Modalities of representation: text, image, audio, and/or video, and the level of synchronicity required.

\section{Personal Learning Environments}

PLEs connect directly with the notion of learner-generated contexts and learners' autonomous learning (Wong, 2013). Although the idea of a personal learning environment has existed for a long time, the emergence of Web 2.0 technologies has enabled a broader range of learning experiences, which cover all the formal and informal educational contexts and give learners the freedom to learn and participate on a global scale (Hirtz \& Harper, 2008; Fullan \& Langworthy, 2014; Salinas, 2008, 2013). From a pedagogical point of view, the PLE includes all the tools, materials, human resources, and learning spaces and places that a learner knows and uses for learning throughout one's life (Adell 
\& Castañeda, 2010; Attwell, 2007; Hilzensauer \& Schaffert, 2008; Väaljataga, Pata, \& Tammets, 2011). In essence, it is a seamless, learner-generated learning environment. Furthermore, the PLE has the potential to promote conciliation between formal and informal learning in educational contexts (Dabbagh \& Kitsantas, 2012; Laakkonen, 2011; Marín \& Salinas, 2014; Peña-López, 2010; Rodríguez Ilera, Rubio, Galván, \& Barberà, 2014). The PLE recognizes the autonomy of learners, so that they can control and manage their own learning processes, and it gives them support so that they may:

1. Define their own learning goals;

2. Manage their own learning, related both to the content and the process;

3. Communicate with others in the learning process; and finally

4. Reach their learning goals (Salinas, 2008, 2013; van Harmelen, 2006).

PLEs are considered to be cognitive tools in a broad sense, which includes the connection with the community and the creation of artifacts. In the design of activities for PLEs, we must also take into account three components: information management, content creation, and connection with others (Castañeda \& Adell, 2013; Wheeler, 2009). Table 1 summarizes the specific activities and resources for each component of the PLE.

\section{SEAMLESS LEARNING ENVIRONMENTS AND MOBILE DEVICES}

Mobile devices can provide possibilities for the creation of seamless learning spaces, transcending physical and social barriers by allowing the access and sharing of multiple representational forms, thus providing a tailored experience to each user (Evans \& Johri, 2008; Lee, Lee, \& Kweon, 2013). Furthermore, they can broaden the settings for collaboration and social interaction between students, extend and provide resources to students, and aid in generating informal and formal learning activities by creating a continuous learning experience across different contexts (Jones \& Jo, 2004; Looi et al., 2010; Naismith, Lonsdale, Vavoula, \& Sharples, 2006). In the context of seamless learning environments, learning is seen as being ubiquitous in nature; it takes place with the aid of mobile devices and enables students to learn in a flexible way, at any location and at any time (Hwang, Tsai, \& Yang, 2008; Lee, Lee, \& Kweon, 2013; Yahya, Ahmad, \& Jalil, 2010). According to Wong and Looi (2011), ten "mobile seamless learning" (MSL) dimensions should be taken into account:

MSL1: Formal and informal learning;

MSL2: Individual and social learning;

MSL3: Learning across time;

MSL4: Learning across locations;

Table 1. Activities and resources for the components of the PLE

\begin{tabular}{|c|c|c|c|}
\hline & Information Management & Content Creation & Connection with Others \\
\hline Activities & $\begin{array}{l}\text { Reading, listening, watching, } \\
\text { searching information }\end{array}$ & $\begin{array}{l}\text { Writing, organizing/structuring, } \\
\text { curating, reflecting, publishing, } \\
\text { summarizing }\end{array}$ & $\begin{array}{l}\text { Sharing, communicating, } \\
\text { discussing, engaging in } \\
\text { dialogues, commenting }\end{array}$ \\
\hline Resources & $\begin{array}{l}\text { Websites, articles, magazines, } \\
\text { newsletters, books, videos, } \\
\text { music, podcasts, TV, radio, } \\
\text { blogs, RSS readers, search } \\
\text { engines, databases, wikis }\end{array}$ & $\begin{array}{l}\text { Concept/mind maps, audio } \\
\text { recorders/editors, cameras, photo } \\
\text { editors, video editors, blogs, } \\
\text { e-portfolios, websites, visual } \\
\text { presentation creators, wikis, } \\
\text { curation services }\end{array}$ & $\begin{array}{l}\text { Social networks and } \\
\text { platforms, email, } \\
\text { videoconferencing systems, } \\
\text { lifestreaming services, } \\
\text { platform sharing }\end{array}$ \\
\hline
\end{tabular}


MSL5: Ubiquitous access to online learning resources;

MSL6: The difference between physical and digital worlds;

MSL7: The combined use of multiple devices;

MSL8: Seamless switching between multiple learning tasks;

MSL9: Knowledge synthesis;

MSL10: Multiple pedagogical or learning activity models.

iPads are one of the available devices that may support the idea of ubiquitous access to learning resources. According to Clark and Luckin (2013, p. 2), "iPads can support seamless learning, allowing learners to easily switch learning contexts - from formal to informal or personal to social—and to take control of their own learning." Similarly, a trial conducted in university classes using iPads highlighted academic and social uses (Mang \& Wardley, 2012). These aspects are key for supporting lifelong learning, and as a connector between the work done inside and outside an educational institution. In addition, a recent systematic review on current research on iPads in higher education by Nguyen, Barton, and Nguyen (2015) found that the use of these devices was not integrated within a holistic teaching and learning approach from the curriculum design and student engagement perspective.

Although the discussion on seamless learning environments with mobile devices or mobileassisted seamless learning environments (Wong \& Looi, 2011) typically presents the possibilities rather than the challenges related to these environments, it is also important to remember that it is neither the device nor the social media that triggers learning mechanisms. The crucial point is how and for what kind of learning tasks the device is used for, and the explicit design for seamless learning activities that foster limitless learning opportunities (Wong, 2013). Furthermore, the teacher's role as a skillful orchestrator of learning activities, and as a manager of constraints, is key in designing seamless learning environments (Dillenbourg \& Jermann, 2010). The current study contributes to the field of seamless learning environments with mobile devices in higher education, and the challenges of its design, using different case studies.

\section{METHOD}

This study was conducted in the context of a university-level project of teaching development implemented at the University of Jyväskylä, Finland. The project aims to develop pedagogically high-quality learning possibilities for students, to support their activities as learners, and to facilitate pedagogically meaningful ways of using information and communication technology (ICT) for learning. Altogether, twelve sub-projects from all the faculties of the university have been involved in the project. While some of the projects are more focused on methodological development, others are focused on technological tools for supporting learning. This study focuses on three cases in which teachers described their learning designs as being seamless, since they aimed to develop mobile, seamless learning environments in their programs.

The particular research questions posed by this study are the following:

RQ1: Which of the learning goals and objectives related to seamless learning environments are facilitated by the educational programs?

RQ2: Which of the pedagogies were developed towards mobile, seamless learning environments while they were being developed?

RQ3: What kinds of seamless learning environment activities and resources are utilized in the educational programs? 


\section{Data Collection and Analysis Procedure}

Three semi-structured interviews were conducted with specific key participants of those concrete sub-projects (four teachers and one program coordinator). This type of interview is characterized by having a flexible and fluid structure, despite having an interview guide or predefined questions/ issues to cover (Mason, 2004).

The themes of the interviews were addressed by the research questions, and focused on learning goals and objectives, learning activities or tasks, type of pedagogy, modalities of representation, and level of synchronicity. They also focused on learning design for the groups related to PLE functions, such as information sources for teaching and planned interactions, as well as activities and resources for content creation, information management, and connection with others.

The interviews were conducted in the midst of carrying out the projects, when the initiatives had advanced from the planning stages to being on the threshold of taking concrete steps. The interviews took an average of one hour for each one of the three sub-projects, and were audio recorded and later transcribed for analysis with a total of written 24 pages. The data was analyzed by utilizing the procedures for qualitative thematic analysis (Braun \& Clarke, 2006) for identifying, analysing and reporting themes within data. The analyses were conducted according to the following steps:

1. Identifying the relevant themes from the whole data. These themes were related to the issues addressed during the interviews, which were described above;

2. Assignation of various themes. The fragments of the interviews were marked by using words that functioned as a label, which identified the theme of that fragment;

3. Classification of relevant information, according to:

a. Learning goals and objectives;

b. Learning activities or tasks (reading, viewing, or listening; collaboration; discussion; investigation; practice; production);

c. Type of pedagogy (transmissive, dialogic, constructive, co-constructive);

d. Modalities of representation (text, image, audio, video);

e. Level of synchronicity (asynchronous and/or synchronous);

f. Information sources for teaching and planned interactions (students, teachers, others);

g. PLE of the case, including: activities and resources for content creation, activities and resources for information management, and activities and resources for connection with others.

The following section summarizes the relevant information related to the research questions of this study; the common aspects of the three case studies are then summarized together.

\section{FINDINGS}

\section{Case Examples}

The following descriptions and excerpts illustrate the main ideas of the interviews conducted with key participants of each sub-project; they focus on the teachers' intentions for seamless learning environments, and not on learning outcomes. As mentioned previously, the interview themes were based on the earlier work of Bower et al. (2010), Laurillard (2012), and Wheeler (2009). Several authors have also identified the characteristics of authentic learning (Lombardi, 2007) and for mobile, seamless learning environments (Wong, 2013; Wong \& Looi, 2011).

In Cases 1 and 3 the interviewee was an only individual, so quotations highlighted are expressions of these particular participants whereas in Case 2 the quotations are expressions of three participant in a group interview. 


\section{Case 1: Smart Sports}

\section{Context and Participants}

This sub-project includes courses related to training for coaches within the Faculty of Sport and Health Sciences. The concrete case is centered on an extracurricular program in which the learning goals and objectives are to develop a new way of thinking about motor learning and skills acquisition through the creation of environments with and without the use of mobile devices:

The framework is that environment is the most effective teacher to learn motor skills and motor behavior. So, the main objective is to emphasize the meaning of environment and how environments can be created that support motor learning and motor behavior.... And of course when we are using mobile technologies and smartphones, etc., we are creating the environment.

In this program, eight to twelve students, who were already experienced, professional coaches, worked in small groups with and without mobile devices, and focused on the transference of these educational practices with their athletes. The program was about five to six months long, and there were four contact days, each lasting eight hours. Between the contact sessions, the students worked remotely, with the support of the teachers (online and sometimes also by phone), but they also had peer support communication online. The distance parts included three-week workload (thirty hours each), and included mostly practical exercises introduced to others during the contact sessions. There were demonstrations on how to support motor learning and skills acquisitions for athletes (with and without different specific coach-related mobile applications); they were then asked to prepare a topic for group discussion related to training athletes.

\section{Devices and Applications}

The student coaches mainly used devices such as mobile phones and tablets, and the applications of their own choice - the core of the course was called "Bring Your Own Device" (BYOD)— to create an environment suitable for enhancing motor learning. These applications were mostly video delays, movement analysis, and film-and-draw types of applications, to allow them to give immediate feedback to their athletes. A few of the student coaches had portable video cameras and computer software for deep analysis.

\section{Learning Activities and Type of Pedagogy}

The tasks for the students were to observe and reflect on:

1. How did these devices and applications enhance athletes' motor skills learning and better participation?

2. What kinds of arrangements are vital for creating mobile technology-supported coaching and teaching?

3. What does mobile technology add to the normal coaching process, and what do the devices and applications lack, from the coach's perspective?

The learning activities and type of pedagogy, conceived in this case, are described in the following example:

The main thing is learning by doing. So, of course we are giving some kind of introduction for the students of what we are going to do with this course and ... the framework of the whole environment is very important. So, then, we are quite quickly moving to demonstrations and actually using the 
smartphones or iPads or what we have in our hands... It is important that the students can create some kind of relationship to the matter we are teaching.

\section{Modalities of Representation}

The interviewee highlighted that all of the modalities of representation were used, as in the following excerpt:

I think we are pretty much using them all, and particularly the mobile technologies .... If we are using a camera or some applications, just a short demonstration of what an application does, see what more you can do with it. So, demonstration is quite important in this. And of course, if necessary we'll keep hangouts going and instructions. Maybe watch some kind of video before.

\section{Level of Synchronicity}

The learning activities planned for the teaching-learning processes at this level included asynchronous and synchronous activities, both inside and outside the class. The level of synchronicity is described in the following example:

The demonstrations that we are doing in these courses, everyone is doing the tasks at the same time.... And if they are doing something with the athletes, they are doing it by themselves. They are not doing it with all the other coaches at the same time. If we give them homework, they can choose when they will do that.

\section{PLE of the Case}

The seamless learning environment of the case, according to the components of PLEs, is based on:

1. Information management: Listening to lectures, using and watching videos from YouTube, reading e-magazines, using the library database, and consulting the www.valmennustaito.info website;

2. Content creation: The core of this element is BYOD, especially using a camera for creating videos and mobile applications for filming and video delay (e.g., BaM ["Bust a Move"] Video Delay, Slow Cam, or Motion Shot), video feedback applications (e.g. Ubersense, Coach's Eye, or CoachMyVideo), and Sprongo (a web-based application for storing, sharing, and analyzing videos). There are also other desktop applications that students can access either from home or from the Research Institute for Olympic Sports (KIHU) (e.g. Dartfish, Silicon Coach, or Kinovea): http://www.kihu.jyu.fi/english/;

3. Connection with others: Face-to-face interaction is important in group discussions and demonstrations. Students also used email and Facebook during the course; the latter included either formal or informal learning interactions.

\section{Case 2: Teachers in the Cloud}

\section{Context and Participants}

This sub-project includes courses related to teacher training within the Faculty of Education. The concrete case is centered on pedagogics, media literacy education, and different school subjects (Finnish language and literature, music, science, and art) that work in a multidisciplinary way, in which the learning goal is to create a new learning environment for the twenty-first century learner. For that purpose, the teachers involved in the sub-project introduced game design and gamification- the use of game mechanics and elements in non-game contexts (Deterding, Dixon, Khaled, \& Nacke, 
2011) - to teacher education. This introduction is also based on an eco-social learning approach, which relates to the dynamic interrelations among personal, social, and environmental factors. They describe the learning goals and objectives as follows:

Our goal is that we are doing things in a way that we think our students should learn, so this is why we work as a group, and they experiment with something new and then they will try to study the results that come from, for example, this game. What kind of learning happens or exists or develops during that process? And of course, the multidisciplinary view combines different subjects, because we deal more with phenomena than isolated subjects, so the things around us are phenomena and we try to grasp those. We want to create a new age learner and create a new learning environment.

"Teachers in the Cloud" is a group of sixteen first-year teacher students who were asked to develop an educational game centered on real-world problems related to consumerism and marketing. They first were introduced to the main background with videos, pictures, recordings, music, and news texts to get them started. Then they all read up on gamification and game design in general; they formed small teams on different topics related to consumerism: entrepreneurs, consumers, and the poor. They then had to build the game based on these inquiries.

The game project lasted the whole academic year (about nine months). Planning and developing the game took most of the time: creating and shaping the story, writing the script, choosing tools and platforms, and creating the materials. After that, the student teachers got feedback from the test game sessions and further fine-tuned the game. In the process, the students worked in small teams and collaborated in face-to-face meetings. Once a month, there were two-hour contact sessions with the teachers, and online communication with the teachers to develop the game and to receive feedback on their ideas.This project is on-going, but it takes the form of a role-playing game.

\section{Devices and Applications}

Although all the students have been given iPads to use, they bring their own devices (such as mobile phones and laptops) to work as well, and they can connect to the Internet anytime and anywhere they want. The students can choose the applications they need for the devices they are using. These applications are mostly for communication, collaboration, teamwork, video and photo editing, music creation, media playback, and social networking services.

\section{Learning Activities and Type of Pedagogy}

The group of 3 participants described learning activities and type of pedagogy as follows:

First we started with watching videos and listening to music, and they were collaborating all the time because they built the game together and we collaborated with the teachers. Also, we were showing teamwork to our students... They are researching gamification, because [they] also learned education and now they are doing the game. There are smaller groups in the student group that research those technology applications that would be helpful in this project, and some of those students are doing research ... on three different groups: entrepreneurs, poor people, and consumers... They are trying to understand those groups better, so that they can build those aspects into the game.

In the whole process, the key element is the idea of modeling a multidisciplinary way of thinking by building teacher communities, in the sense that as lecturers work together, students will do so as well. The importance of experimental learning was also important: the student teachers related their own experiences in game design in order to transfer it to their future jobs as schoolteachers. 


\section{Modalities of Representation}

The interviewees stressed that while all of the modalities of representation are combined, the main thing is discussion, as can be seen in the following excerpt:

I think it's combined. We talk a lot and discuss things. I think that's the main thing. But we should understand, know, and research something before we can discuss it properly. So, then reading and watching videos and the same stuff [similar types of activities] is involved.

\section{Level of Synchonicity}

The learning activities planned for the teaching-learning processes at this level included asynchronous and synchronous activities, inside and outside the class. The flexibility related to the level of synchronicity for the learning activities, which is described in the following excerpt, is remarkable:

They can plan the schedule themselves, and we just tell them that they should do the stuff [the works] at the time.

\section{PLE of the Case}

The seamless learning environment of this sub-project, according to the components of PLEs, is based on:

1. Information management: Using the Internet (including watching videos on YouTube), radio, $\mathrm{TV}$, and reading articles from the library database;

2. Content creation: Creating visual presentations with Prezi and Keynote, videos with iMovie, collaborative documents with Google Drive, music with GarageBand, presentations and videos with Explain Everything, documents with Pages, and collaborative creations using the Facetime videoconferencing system;

3. Connection with others: Face-to-face work seminars and meetings; sharing documents and schedules in Peda.net (a virtual environment developed and maintained by the University of Jyväskylä, with a set of Web tools especially for schools, but also used in the university, that supports the creation of personal and course spaces: http://peda.net/en/index.php); the use of email, blogs, chats, and Instagram; videoconferencing with Facetime; using WhatsApp for informal communications in a group; sharing videos on Vimeo; sharing documents with Google Drive; and communicating and sharing privately within a Facebook-closed group, and publicly via a Facebook public page.

\section{Case 3: Music Technology}

\section{Context and Participants}

This sub-project includes courses related to training music technology teachers within the Department of Music. The concrete case has not yet been fully implemented, but will be centered on different music-related courses in which mobile music technology could be used. Learning goals and objectives associated with the courses (to different extent and uses) are related to the development of skills for music recording, editing, processing, etc., using mobile devices and learning environments so that students can transfer them to their forthcoming jobs:

We might talk about some synthesizer or computer-based composition or improvisation, or maybe we might talk about new music interfaces like embodied interfaces, variable class, and stuff like that. So there is a lot of topic subject-related goals. They must know and learn these kind of basic things 
related to these topics but, of course, we have some kind of side goals with technology, sort of that they can learn how to use technology in a fluent way within different kinds of topics and subjects. The main aims are related to recording, music recording, editing, processing, these kind of things, ... so that they can use these approaches in their own forthcoming jobs, in music they compose, whether they are working as musical researchers, music educators in schools, or as music therapists.

\section{Learning Activities and Type of Pedagogy}

As was mentioned before, this case is in its initial phases. The first phase was centered on the groundwork of mobile applications suitable for music purposes. This research has been done in collaboration between the professor and a group of five students in a project course, collecting data and information on mobile devices for music purposes and testing how they actually work. The group actively used a Facebook group for their internal communication. After this investigation, they conducted a workshop to share and discuss their findings. Although the background for the work was established in 2008, this specific action was carried out during the first semester of 2014. Music education is a good example of having formal and informal learning contexts. The interviewee described learning activities and type of pedagogy in this initial work as follows:

We had a student group within this last semester called 'Mukamoba' group; it means in Finnish that it is a music education-related and mobile technology-related group. And they've been doing a project course, ... this kind of background work related to applications. So, [we] have collected data and information of how these applications work, and from that groundwork I have been proposing some of these applications for our teachers. There has been some collaboration within the students and I have been collaborating with those students as well.

Then, these applications were categorized depending on their uses in the music field, and the professor started working with the other lecturers of the Department of Music. They first discussed their former, current, and future pedagogies, and they later proposed that some of the musical apps be incorporated into their teaching, according to the suitability to their teaching topics and pedagogy. They then had to select one or two of them, test them, and put them into practice in their teaching.

\section{Devices and Applications}

Lecturers will use demos of these mobile applications suitable for music purposes before students work with them. Concerning devices, although the idea is to use BYOD in the future, at the moment both students and lecturers borrow the mobile devices from the department, which are mainly iPads.

\section{Modalities of Representation}

The interviewee highlighted that all of the modalities of representation were integrated, especially the media forms, as can be seen in the following excerpt:

In music learning technologies, that's a broad topic. We try to integrate all possible media forms, because music is a multimodal language in many ways. It's embodied language, it's visual language through notes, musical notation, it's audible language through audio wave forms. So, there are many modalities in music. So, that's why we try to integrate all of those somehow.

\section{Level of Synchonicity}

The learning activities planned for the teaching-learning processes at this level included asynchronous and synchronous activities, both inside and outside the class. The level of synchronicity is described in the following example: 
In our approach we try to see music learning as a formal and informal activity, which happens inside our institution and outside our institution, our department of music.... We tend to think that in university teaching and learning philosophy, interaction with other students is really important. So, we think that mobile technology can give some more tools to students to collaborate and cooperate with each other, if they are not in the same place, for example. They can do some group work, different places, different times.

\section{PLE of the Case}

The seamless learning environment of the initial work in this sub-project, according to the components of PLEs, is based on:

1. Information management: Reading notes on Evernote, listening to music on Spotify and Tuneln radio, reading music notations on ForScore and Avid Scorch, scanning music notations with Scanner Pro, watching YouTube and TED videos, and reading presentations on Prezi;

2. Content creation: Writing notes on Evernote, creating music with GarageBand and Cubasis, recording video with Movie Pro, doing audio recording with Hokusai, making notations with Notion, taking and editing photos with Camera+, and creating learning materials with Book Creator. One example of a more specific application is to use DM1, as a drum machine;

3. Connection with others: Sharing links on Edmodo, videoconferencing on Skype (still not used very often), emailing, sharing learning materials and music on Dropbox, sharing and commenting audio on Soundcloud, doing collaborative notation with Moxtra, and sharing and writing documents in Google Drive.

\section{DISCUSSION AND CONCLUSION}

All the cases of this study had some common aspects that grouped them into the design of authentic and mobile seamless learning environments (Wong \& Looi, 2011). Regarding learning goals and objectives linked to seamless learning environments (RQ1), they all promoted real-world relevance of activities oriented toward the students' future professional performance: training coaches (case 1), teaching at school (case 2), or music workers, such as musical researchers, music educators at school, or music therapists (case 3). Furthermore, in all the cases, a variety of technologies (MSL7) was utilized for multiple tasks (MSL8) as information management, knowledge creation, and communication purposes (RQ3).

The active participation from students is required because the focus in all the learning activities proposed was learning by doing, mixing the different kinds of learning activities (MSL10) listed by Laurillard (2012), which refers to the kinds of seamless learning environment activities and resources utilized (RQ3). These activities involve ill-defined problems that are not solved easily by applying a simple or existing procedure; they have multiple interpretations and possible outcomes and no single, correct answer. These problems also comprise complex learning tasks, to be investigated by students using a variety of resources, making choices and reflecting on their learning. Their consequences extended beyond a particular discipline, so interdisciplinarity is important (MSL9); this is especially remarkable in case 2 .

The learning outcomes of the sub-projects were assessed integratively; they combine different possible modalities of representation: an artifact for discussion (case 1), an educational game (case 2), and creations with mobile music technology (case 3).

Concerning the pedagogies developed towards mobile, seamless learning environments (RQ2), the type of pedagogy used in each case was also mixed (MSL10), but all of the cases focused on more dialogic and co-constructive pedagogical approaches (Bower, Hedberg, \& Kuswara, 2010). Collaboration and sharing thus were important in all three cases. In case 1, participants collaborated to 
fine-tune their previous work in the group discussions and also with the athletes. In case 2, collaboration was always present between students and teachers; it was also performed with other students from the same studies and from a different institute within the university, and with teachers in partner schools. In case 3, although it is still in the beginning phase, collaboration was also promoted between students and teachers, and is expected to go beyond the class, as well as taking into account other institutions.

A mobile, seamless learning environment was perceived in all cases, since virtual and physical (MSL6); personal/individual and social (MSL2); and formal and informal environments (MSL1) were integrated without boundaries distinction. This can be seen from the uses of different activities and resources described in the cases' learning environments. The same applies for the level of synchronicity: learning at any time and in any location (MSL3 and MSL4). Collaboration and sharing, information management, and access to learning resources and content creation (MSL5) were done interchangeably with resources from formal and informal contexts, and virtual and physical environments. The mobile devices used, in all cases tablet devices (especially iPads), were conceived as mediators and cognitive tools that enhanced the creation of these ubiquitous and seamless learning spaces.

Therefore, all the components of seamless learning environments posed by Seow et al. (2008) were present: diversity of spaces, flexibility of time, a context for the designed activities, different actors in the learning community, and mobile devices and applications as cognitive tools and expected artifacts produced by the learners. The ten MSL dimensions proposed by Wong and Looi (2011) were also highlighted and related to the different research questions of the study.

\section{LIMITATIONS OF THE STUDY, AND FUTURE RESEARCH AGENDA}

The elements identified in the cases can be considered in designing future scenarios for seamless learning environments with mobile devices in the context of higher education. Nevertheless, assessment and validation of the learning designs by different sources—and especially by students—will be necessary in order to confirm that they are suitable designs and to generalize them, according to other contexts' settings. Further work on the project will be required in order to track the implementation of the learning designs and the outcomes of this deployment.

This study does have some limitations. The focus of this paper is on three specific cases from a national teaching project in Finland. Furthermore, the point of view shown in the study only represents the teachers' point of view; the students' perspective is not included. In addition, the methodological approach is based exclusively on a qualitative perspective, using interviews. Data triangulation should be considered in future work.

Despite these limitations, challenges in designing seamless learning environments and the implementation of PLEs can be identified and must be considered in our future research agenda. Earlier research has indicated that deeper level learning and collaboration does not just happen when people come together (Häkkinen et al., 2010): there are challenges related to learners' skills, teachers' roles, and other circumstances of learning and collaboration. One of the major challenges is how to design many-sided pedagogical practices that enhance activity in thinking and strategic learning skills, as well as meaningful learning and collaboration processes. There are also claims that many learning environments are minimally structured (Kirschner, Sweller, \& Clark, 2006), and hence do not generate productive and knowledge-generative activities such as argumentation, questioning, or explaining (Kobbe et al., 2007). This critique can also easily be applied to seamless learning environments, which raises the importance of theory-based design of these environments. Although mobile technology's potential is that it is present for learning purposes when needed, the core focus should be folding the intellectual, social, and creative activities that students are engaged in into seamless learning environments with mobile devices. In this sense, the challenge is the one referred to earlier: including curriculum design and pedagogical thinking behind the use of mobile devices (Wong \& Looi, 2011). 
One approach that aims to integrate informal and formal learning settings is related to PLE. The learning experiences that they enable are usually active, process-based, and anchored in (and driven by) learners' interests; therefore, these experiences have the potential to cultivate independent, self-regulated learning (Attwell, 2007; McLoughlin \& Lee, 2010). In order to become self-regulated learners, however, they need to have previously developed metacognitive knowledge and competencies: the motivation to analyze, control, and improve their learning (Dabbagh \& Kitsantas, 2012; Hannafin \& Land, 2000).

\section{ACKNOWLEDGMENT}

This work is framed within the research project EDU2011-25499 Methodological strategies for integrating institutional virtual environments, personal and social learning, developed by the Educational Technology Group (GTE) of the University of the Balearic Islands between 2012 and 2015 and funded by the Ministry of Education and Science of Spain, within the National Programme for Fundamental Research. We would also like to thank all of the teachers of the teaching development project who participated in the interviews, as well as the Center for International Mobility (CIMO) of Finland for the economic support in the research collaboration between the University of Jyväskylä and the University of the Balearic Islands. 


\section{REFERENCES}

Adell, J., \& Castañeda, L. (2010). Los Entornos Personales de Aprendizaje (PLEs): una nueva manera de entender el aprendizaje. In R. Roig Vila \& M. Fiorucci (Eds.), Claves para la investigación en innovación y calidad educativas. La integración de las Tecnologías de la Información y la Comunicación y la Interculturalidad en las aulas. Strumenti di ricerca per l'innovazione e la qualità in ámbito educativo. Le Tecnologie dell'informazione e della Comunicazione e l'interculturalità nella scuola. Alcoy: Marfil - Roma TRE Università degli studi.

Attwell, G. (2007). Personal learning environments - the future of eLearning? In eLearning Papers (Vol. 2, pp. $1-8)$. Retrieved from http://www.elearningpapers.eu

Bower, M., Hedberg, J. G., \& Kuswara, A. (2010). A framework for Web 2.0 learning design. Educational Media International, 47(3), 177-198. doi:10.1080/09523987.2010.518811

Braun, V., \& Clarke, V. (2006). Using thematic analysis in psychology. Qualitative Research in Psychology, 3(2), 77-101. doi:10.1191/1478088706qp063oa

Butson, R. (2005). The Role of Faculty in the Digital Education of Tomorrow. Journal of Computing in Higher Education, 17(1), 3-16. doi:10.1007/BF02960224

Castañeda, L., \& Adell, J. (2013). La anatomía de los PLEs. In Entornos Personales de Aprendizaje: Claves para el ecosistema educativo en red (pp. 11-27). Alcoy: Marfil.

Chan, T.-W., Roschelle, J., Hsi, S., Sharples, M., Brown, T., Patton, C., \& Hoppe, U. (2006). One-to-one technology enhanced learning: An opportunity for global research collaboration. Research and Practice in Technology Enhanced Learning, 1(1), 3-29. doi:10.1142/S1793206806000032

Clark, W., \& Luckin, R. (2013). iPads in the Classroom. London. Retrieved from https://www.lkldev.ioe.ac.uk/ lklinnovation/wp-content/uploads/2013/01/2013-iPads-in-the-Classroom-v2.pdf

Conole, G. (2007). Describing learning activities: Tools and resources to guide practice. In H. Beetham \& R. Sharpe (Eds.), Rethinking Pedagogy for a Digital Age: Designing and Delivering E-Learning (pp. 81-91). London: RoutledgeFalmer.

Dabbagh, N., \& Kitsantas, A. (2012). Personal Learning Environments, social media, and self-regulated learning: A natural formula for connecting formal and informal learning. The Internet and Higher Education, 15(1), 3-8. doi:10.1016/j.iheduc.2011.06.002

Deterding, S., Dixon, D., Khaled, R., \& Nacke, L. (2011). From Game Design Elements to Gamefulness: Defining "Gamification." Proceedings of MindTrek'11 the 15th International Academic MindTrek Conference: Envisioning Future Media Environments (pp. 9-15). New York, NY, USA: ACM.

Dillenbourg, P., \& Jermann, P. (2010). Technology for Classroom Orchestration. In M. S. Khine \& I. M. Saleh (Eds, Trans.), The New Science of Learning: Computers, Cognition and Collaboration in Education (pp. 525552). New York, NY: Springer. doi:10.1007/978-1-4419-5716-0_26

Elen, J., Clarebout, G., Léonard, R., \& Lowyck, J. (2007). Student-centred and teacher-centred learning environments: What students think. Teaching in Higher Education, 12(1), 105-117. doi:10.1080/13562510601102339

Evans, M. A., \& Johri, A. (2008). Facilitating guided participation through mobile technologies: Designing creative learning environments for self and others. Journal of Computing in Higher Education, 20(2), 92-105. doi:10.1007/s12528-008-9004-1

Fullan, M., \& Langworthy, M. (2014). A rich seam: How new pedagogies find deep learning. London.

Häkkinen, P., Arvaja, M., Hämäläinen, R., \& Pöysä, J. (2010). Scripting Computer-Supported Collaborative Learning: A Review of SCORE Studies. In B. Ertl (Ed.), E-Collaborative Knowledge Construction: Learning from Computer-Supported and Virtual Environments (pp. 180-194). IGI Global. doi:10.4018/978-1-61520729-9.ch010

Häkkinen, P., \& Hämäläinen, R. (2012). Shared and personal learning spaces: Challenges for pedagogical design. The Internet and Higher Education, 15(4), 231-236. doi:10.1016/j.iheduc.2011.09.001 
Hannafin, M. J., \& Land, S. M. (2000). Technology and Student-Centered Learning in Higher Education: Issues and Practices. Journal of Computing in Higher Education, 12(1), 3-30. doi:10.1007/BF03032712

Hilzensauer, W., \& Schaffert, S. (2008). On the way towards Personal Learning Environments: Seven crucial aspects. Elearning Papers, 9. Retrieved from http://www.elearningpapers.eu/en/elearning_papers

Hirtz, S., \& Harper, D. G. (Eds.). (2008). Education for a digital world: Advice, guidelines, and effective practice from around the globe. Vancouver, Canada: Commonwealth of Learning \& BCcampus.

Hutchins, E. (1995). Cognition in the Wild. MIT Press.

Hwang, G.-J., Tsai, C.-C., \& Yang, S. J. H. (2008). Criteria, Strategies and Research Issues of Context-Aware Ubiquitous Learning. Journal of Educational Technology \& Society, 11(2), 81-91.

Johnson, L., Adams Becker, S., Estrada, V., \& Freeman, A. (2014). The NMC Horizon Report: 2014 Higher Education Edition. Austin, Texas. Retrieved from http://cdn.nmc.org/media/2014-nmc-horizon-report-he-ENSC.pdf

Jones, V., \& Jo, J. H. (2004). Ubiquitous learning environment: An adaptive teaching system using ubiquitous technology. In R. Atkinson, C. McBeath, D. Jonas-Dwyer, \& R. Phillips (Eds.), Beyond the comfort zone: Proceedings of the 21st ASCILITE Conference (pp. 468-474). Perth, Australia.

Kereluik, K., Mishra, P., Fahnoe, C., \& Terry, L. (2013). What Knowledge Is of Most Worth: Teacher Knowledge for 21st Century Learning. Journal of Digital Learning in Teacher Education, 29(4), 127-140. doi:10.1080/2 1532974.2013.10784716

Kirschner, P. A., Sweller, J., \& Clark, R. E. (2006). Why minimal guidance during instruction does not work: An analysis of the failure of constructivist, discovery, problem-based, experiential, and inquiry-based teaching. Educational Psychologist, 41(2), 75-86. doi:10.1207/s15326985ep4102_1

Kobbe, L., Weinberger, A., Dillenbourg, P., Harrer, A., Hämäläinen, R., Häkkinen, P., \& Fischer, F. (2007). Specifying Computer-Supported Collaboration Scripts. International Journal of Computer-Supported Collaborative Learning, 2(2-3), 211-224. doi:10.1007/s11412-007-9014-4

Kuh, G. D. (1996). Guiding principles for creating seamless learning environments for undergraduates. College Student Development, 37(2), 135-148.

Laakkonen, I. (2011). Personal learning environments in higher education language courses: an informal and learner-centred approach. In S. Thouësny, \& L. Bradley (Eds.), Second Language Teaching and Learning with Technology: Views of Emergent Researchers (Vol. 1, pp. 9-28). Dublin, Ireland: Research-Publishing.net. doi:10.14705/rpnet.2011.000004

Laurillard, D. (2012). Teaching as a Design Science: Building Pedagogical Patterns for Learning and Technology. New York, London: Routledge.

Lee, H., Lee, W. B., \& Kweon, S. C. (2013). Conjoint analysis for mobile devices for ubiquitous learning in higher education: the Korean case. The Turkish Online Journal of Educational Technology, 12(1).

Lombardi, M. M. (2007). Authentic Learning for the 21st Century: An Overview. EDUCAUSE Learning Initiative.

Looi, C.-K., Seow, P., Zhang, B., So, H.-J., Chen, W., \& Wong, L.-H. (2010). Leveraging mobile technology for sustainable seamless learning: A research agenda. British Journal of Educational Technology, 41(2), $154-169$. doi:10.1111/j.1467-8535.2008.00912.x

Mang, C. F., \& Wardley, L. J. (2012). Effective Adoption of Tablets in Post-Secondary Education: Recommendations Based on a Trial of iPads in University Classes. Journal of Information Technology Education: Innovations in Practice, 11, 301-317.

Marín, V. I., \& Salinas, J. (2014). First Steps in the Development of a Model for Integrating Formal and Informal Learning in Virtual Environments. In S. Leone (Ed.), Synergic Integration of Formal and Informal E-Learning Environments for Adult Lifelong Learners (pp. 142-164). Hershey, PA, USA: IGI Global. doi:10.4018/978-14666-4655-1.ch007 
Mason, J. (2004). Semistructured Interview. In Michael S. Lewis-Beck, A. Bryman, \& Tim Futing Liao (Eds.), The SAGE Encyclopedia of Social Science Research Methods. (pp. 1021-1022). Thousand Oaks, CA: Sage Publications, Inc. doi:10.4135/9781412950589.n909

McLoughlin, C., \& Lee, M. J. W. (2010). Personalised and self regulated learning in the Web 2.0 era: International exemplars of innovative pedagogy using social software. Australasian Journal of Educational Technology, 26(1), 28-43.

Motschnig-Pitrik, R., \& Holzinger, A. (2002). Student-Centered Teaching Meets New Media: Concept and Case Study. Journal of Educational Technology \& Society, 5(4).

Naismith, L., Lonsdale, P., Vavoula, G., \& Sharples, M. (2006). Literature Review in Mobile Technologies and Learning. FutureLab Series, Report 11. University of Birmingham.

Nguyen, L., Barton, S. M., \& Nguyen, L. T. (2015). iPads in higher education-Hype and hope. British Journal of Educational Technology, 46(1), 190-203. doi:10.1111/bjet.12137

Peña-López, I. (2010). Funnelling concepts in Education 2.0: PLE, e-Portfolio, Open Social Learning. ICTlogy, \#78, March 2010. Retrieved from http://ictlogy.net/review/?p=3323

Rodríguez Ilera, J. L., Rubio, M. J., Galván, C., \& Barberà, E. (2014). Diseño de un entorno mixto e-portfolio/ ple centrado en el desarrollo de competencias transversales. EDUTEC, Revista Electrónica de Tecnología Educativa, 47.

Salinas, J. (2008). Algunas perspectivas de los entornos personales de aprendizaje. Proceedings of TICEMUR 2008. III Jornadas Nacionales TIC y Educación. Lorca, Murcia.

Salinas, J. (2012). La investigación ante los desafíos de los escenarios de aprendizaje futuros. RED (Revista de Educación a Distancia), 32.

Salinas, J. (2013). Enseñanza Flexible y Aprendizaje Abierto, Fundamentos clave de los PLEs. In L. Castañeda \& J. Adell (Eds.), Entornos personales de aprendizaje: Claves para el ecosistema educativo en red (pp. 53-70). Alcoy: Marfil.

Seow, P., Zhang, B. H., So, H.-J., Looi, C.-K., \& Chen, W. (2008). Towards A Framework for Seamless Learning Environments. Proceedings of ICLS'08 the 8th international conference for the learning sciences (Vol. 2, pp. 327-334).

Sharples, M. (Ed.). (2006). Big issues in mobile learning: report of a workshop by the Kaleidoscope network of excellence mobile learning initiative. LSRI. University of Nottingham.

The Partnership for 21st Century Skills. (2009). 21st Century Learning Environments White Paper. Retrieved from http://www.p21.org/storage/documents/le_white_paper-1.pdf

Väaljataga, T., Pata, K., \& Tammets, K. (2011). Considering students' perspectives on personal and distributed learning environments in course design. In M. J. W. Lee \& C. McLoughlin (Eds.), Web 2.0-Based E-Learning: Applying Social Informatics for Tertiary Teaching. United States of America: Information Science Reference. doi:10.4018/978-1-60566-294-7.ch005

Van Harmelen, M. (2006). Personal Learning Environments. Proceedings of the Sixth IEEE International Conference on Advanced Learning Technologies (ICALT'06) (pp. 815-816). doi:10.1109/ICALT.2006.1652565

Wheeler, S. (2009). It's Personal: Learning Spaces, Learning Webs. Blog entry in Learning with " $e$ "s. Retrieved from http://steve-wheeler.blogspot.com.es/2009/10/its-personal-learning-spaces-learning.html

Wong, L.-H. (2013). Analysis of Students' After-School Mobile-Assisted Artifact Creation Processes in a Seamless Language Learning Environment. Journal of Educational Technology \& Society, 16(2), 198-211.

Wong, L.-H., \& Looi, C.-K. (2011). What seams do we remove in mobile-assisted seamless learning? A critical review of the literature. Computers \& Education, 57(4), 2364-2381. doi:10.1016/j.compedu.2011.06.007

Yahya, S., Ahmad, E. A., \& Jalil, K. A. (2010). The definition and characteristics of ubiquitous learning: A discussion. International Journal of Education and Development using Information and Communication Technology, 6(1), 117-127. 
Victoria I. Marín is associate lecturer and post-doctoral researcher on Educational Technology in the Department of Applied Pedagogy and Educational Psychology of the University of the Balearic Islands (Spain).

Päivikki Jääskelä is a post-doctoral researcher on higher education pedagogy in the multidisciplinary network project for developing university teaching. She also works as a university teacher on educational sciences at the Department of Teacher Education, University of Jyvaskyla (Finland).

Päivi Häkkinen is a professor of educational technology at the Finnish Institute for Educational Research (FIER) in University of Jyväskylä. She is leading the research area on ICT in learning environments. Her main research interests are related to computer-supported collaborative learning, assessment of collaborative problem solving skills, design and evaluation of learning environments as well as 21 st century teacher training. She has actively published in national and international journals, and she has also been invited to many national and international scientific tasks (e.g. member in international programme committees of conferences, referee in journals, expert duties in doctoral training). She has long-term experience in leading research projects and in collaborating with leading national and international research groups in the area of learning and learning technologies.

Merja Juntunen is a project researcher and an educator in the Department of Teacher Education at the University of Jyväskylä. Her research and teaching focus on educational technology, personal learning environments (PLEs) and a student teachers' professional development in ICT.

Helena Rasku-Puttonen is a professor of Psychology in Education. Her areas of interest include collaboration and social interaction in school and working life contexts, learning environments.

Mikko Vesisenaho specializes in blended, technology enhanced education, and contextual design. His professional career consists of research in the educational and ICT sectors in collaboration with higher education institutions, schools and companies. Currently he works as a research coordinator at the human technology unit Agora Center, University of Jyväskylä, Finland. He has over 60 peer review journal and conference articles published in the international venues based on his academic and practical background from Education and Computer Science. 


\title{
Call for Articles
}

\section{International Journal of Mobile and Blended Learning}

\author{
Volume 8 • Issue 1 • January-March 2016 • ISSN: 1941-8647 • elSSN: 1941-8655
}

An official publication of the Information Resources Management Association

\section{MISSION}

The primary mission of the International Journal of Mobile and Blended Learning (IJMBL) is to provide comprehensive coverage and understanding of the role of innovative learning theory and practice in an increasingly mobile and pervasive technological environment. As technology enables a more seamless experience of device supported learning worlds that may integrate mobile, embedded, augmented, and immersive technologies, we may expect to see increasing interest and activity in blended approaches to learning. IJMBL brings together researchers at the forefront of this field, in both technology and pedagogical practice and assists them in the development and dissemination of new approaches to both mobile and blended learning.

\section{COVERAGE AND MAJOR TOPICS}

The topics of interest in this journal include, but are not limited to:

Comprehensive or critical reviews of the current literature $\bullet$ Evaluation of mobile or blended learning in practice - Future of mobile or blended learning $\bullet$ Knowledge Sharing $\bullet$ Learner interaction/collaborative learning $\bullet$ Mobile games for learning $\bullet$ Mobile or blended learning applications $\bullet$ Mobile or blended learning applied at different levels of education from pre-school to tertiary and beyond $\bullet$ Pedagogical and/or philosophical underpinnings of mobile or blended learning • Privacy and security issues • Related research in learning, including e-learning and pedagogical approaches $\bullet$ Resource constraints in the delivery of mobile or blended learning $\bullet$ Reviews of the application of mobile or blended learning in multiple contexts • Role of Wikis, blogs, podcasts, messaging, other online tools, and Web 2.0 components in learning delivery • Roles of mobile, pervasive, and immersive technologies in education $\bullet$ Technologies that directly or indirectly support mobile or blended learning systems (devices, networks, tools etc.) $\bullet$ Theoretical approaches to mobile or blended learning solutions $\bullet$ Use of mobile or blended learning in professional environments

\section{ALL INQUIRIES REGARDING IJMBL SHOULD BE DIRECTED TO THE ATTENTION OF:}

David Parsons, Editor-in-Chief•IJMBL@igi-global.com

ALL MANUSCRIPT SUBMISSIONS TO IJMBL SHOULD BE SENT THROUGH THE ONLINE SUBMISSION SYSTEM: http://www.igi-global.com/authorseditors/titlesubmission/newproject.aspx

IDEAS FOR SPECIAL THEME ISSUES MAY BE SUBMITTED TO THE EDITOR(S)-IN-CHIEF

\section{PLEASE RECOMMEND THIS PUBLICATION TO YOUR LIBRARIAN}

For a convenient easy-to-use library recommendation form, please visit: http://www.igi-global.com/IJMBL 